\title{
Human rights abuses in local government areas in Nigeria during the coronavirus disease 2019 pandemic: Faith-based organisations as agents of transformation
}

\begin{tabular}{|c|c|}
\hline \multicolumn{2}{|c|}{$\begin{array}{l}\text { Authors: } \\
\text { Favour C. Uroko }{ }^{1} \text { ( } \\
\text { Chinyere T. Nwaoga }\end{array}$} \\
\hline \multicolumn{2}{|c|}{$\begin{array}{l}\text { Affiliations: } \\
{ }^{1} \text { Department of Religion and } \\
\text { Cultural Studies, Faculty of } \\
\text { Social Sciences, University } \\
\text { of Nigeria, Nsukka, Nigeria }\end{array}$} \\
\hline \multicolumn{2}{|c|}{$\begin{array}{l}\text { Corresponding author: } \\
\text { Chinyere Nwaoga, } \\
\text { chinyere.nwaoga@unn.edu.ng }\end{array}$} \\
\hline \multicolumn{2}{|c|}{$\begin{array}{l}\text { Dates: } \\
\text { Received: } 13 \text { Oct. } 2020 \\
\text { Accepted: } 15 \text { Mar. } 2021 \\
\text { Published: } 30 \text { Apr. } 2021\end{array}$} \\
\hline \multicolumn{2}{|c|}{$\begin{array}{l}\text { How to cite this article: } \\
\text { Uroko, F.C. \& Nwaoga, C.T., } \\
2021 \text {, 'Human rights abuses } \\
\text { in local government areas in } \\
\text { Nigeria during the } \\
\text { coronavirus disease } 2019 \\
\text { pandemic: Faith-based } \\
\text { organisations as agents of } \\
\text { transformation', Journal of } \\
\text { Local Government Research } \\
\text { and Innovation 2(0), a25. } \\
\text { https://doi.org/10.4102/ } \\
\text { jolgri.v2i0.25 }\end{array}$} \\
\hline \multicolumn{2}{|c|}{$\begin{array}{l}\text { Copyright: } \\
\text { (c) 2021. The Authors. } \\
\text { Licensee: AOSIS. This } \\
\text { is licensed under the } \\
\text { Creative Commons } \\
\text { Attribution License. }\end{array}$} \\
\hline \multicolumn{2}{|l|}{ Read online: } \\
\hline 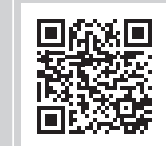 & $\begin{array}{l}\text { Scan this QR } \\
\text { code with your } \\
\text { smart phone or } \\
\text { mobile device } \\
\text { to read online. }\end{array}$ \\
\hline
\end{tabular}

Background: There were cases of human rights abuse during the coronavirus disease 2019 (COVID-19) pandemic in the Warri, Uyo, Afikpo, Aba North, Kaduna South and Idemili North local government areas. Indigenes of these areas went through excruciating pain and suffering after the declaration of total lockdown by their state governments. The state governments declared lockdown, with no (or inefficient) distribution of palliatives to the indigenous population.

Aim: This article examines human rights abuses perpetrated whilst the victims were in the same vicinity as their aggressors during the lockdown occasioned by the coronavirus.

Setting: The data were collected from the Warri, Uyo, Afikpo, Aba North, Kaduna South and Idemili local government areas.

Methods: The phenomenological method of qualitative research was used in the study. Data were collected from official government documents, gazettes, and faith-based organisation (FBOs). The data collected were analysed descriptively.

Results: Corruption among security personnel, the lack of sensitisation and training of security personnel by the government on the rules of engagement and the Lack of punishment of security personnel after their abuse of power are the motivating factors to the human rights abuses during the coronavirus pandemic in Nigeria.

Conclusion: Citizens were forced to go out to look for money and food to buy. These citizens were engaged by security agents (enforcing the lockdown) and were harassed and killed. The findings reveal that lack of special training for COVID-19 security personnel, corruption and lack of sensitisation are the reasons for these cases of human rights abuse. Faith-based organisations have roles to play towards achieving a reduction in the escalating cases of human rights abuse in these areas.

Keywords: COVID-19 pandemic; FBOs; insecurity; security agents; Nigeria; corruption.

\section{Introduction}

Insecurity and security agents have been part of the social issues militating against the safety of the indigenes of the Warri, Uyo, Afikpo, Aba North, Kaduna South and Idemili North local government areas (LGAs). One would think that during the period of crisis, security agents would metamorphose into becoming agents of protection for the indigenous population, but the coronavirus disease 2019 (COVID-19) pandemic has solidified the traditionally held belief of security agents being part of Nigeria's insecurity. Nigeria's security agencies had a 'bad reputation for brutality, extortion, and harassment even before the current coronavirus pandemic and the lockdown imposed to contain the virus' (Khalid 2020:1). On 31 March 2020, the federal government of Nigeria announced a total lockdown in selected states. This was because of the first recorded case of the new virus known as COVID-19 on 25 February 2020.

After this declaration, the governors of the states of Delta, Akwa Ibom, Ebonyi, Abia, Kaduna and Anambra in Nigeria took a drastic step aimed at protecting their citizens from being infected with coronavirus by declaring a total lockdown in their states (Amzat et al. 2020; BBC 2020; Garda 2020; Fuwape, Okpalaonwuka \& Ogunjo 2021; NAN 2020). Thus, security agents 
became empowered to assist the executive by enforcing the legislation (Aborisade 2021). Thirteen security agencies were empowered to enforce the lockdown in the aforementioned states. This was to reduce the movement of people, and it may have reduced the increasing number of cases as well as the spread to other states (Omaka-Amari et al. 2000:94).

It was reported that essential food items and money were distributed to the citizens to cushion the hardship on them. Unfortunately, the elites behind the distribution of the money and items were able to manipulate the system and in the process enrich themselves and their families, as a result of inaccuracies in the statistical database listing the real poor Nigerians (Tijani 2020). A rise in death rates was reported in the print and electronic media in Nigeria. Unfortunately, this rise in death rates was not caused by the COVID-19 pandemic, but by the killings carried out by security agents. For instance, a 28-year-old man in Warri was killed on 02 April 2020 by the army for being out during the lockdown (Adurokiya \& Agborh 2020). In Aba, a tricycle rider was killed by a security agent on 16 April 2020 (Alaribe \& Ugbor 2020:1). It was on this basis that Amnesty International concluded that the behaviour of the Nigerian police in the enforcement of COVID-19 measures was not perceived by human rights organisations and the civil populace as procedurally just (Amnesty International 2020).

The families of victims were left to grieve their husbands and sons with no compensation. Security personnel continued in their abuse of the civil and religious rights of the people. The government seemed to be completely overwhelmed with setting up isolation centres and procuring appropriate drugs. Meanwhile, the role of faith-based organisation (FBOs) was seriously sidelined during coronavirus. It is on this basis that this article examines the spate of excess abuses of human rights by security agencies in Nigeria and the role of FBOs in finding solutions to this problem.

Whilst literature on the deaths emanating from the COVID-19 pandemic and the number of new infections is readily available, literature on the insecurity of lives in Warri, Uyo, Afikpo, Aba North, Kaduna South and Idemili North LGAs during the pandemic is scant. Thus, the aim of this study is to fill this gap in the literature by highlighting the social and economic roles of FBOs in combating the present security challenges during this COVID-19 pandemic.

Firstly, this article examines the COVID-19 pandemic in Nigeria. Secondly, it looks into the causes of the abuse of human rights by security agencies. Thirdly, it assesses the impacts of the irregular killings and also explores the roles of FBOs in curbing this sad development. It is believed that the engagement of FBOs will speak anew to the security challenges in these LGAs.

\section{Methodology and approach to the study}

Human rights abuse became the norm during the coronavirus pandemic. In order to outline the depths of this abuse, the phenomenological method was used. The method aims to describe, understand and interpret the meanings of experiences of human life (Bloor \& Wood 2006). Data from official documents of the Nigeria Centre for Disease Control (NCDC), National Human Rights Commission (NHRC), Federal Ministry of Health (FMH), World Health Organization (WHO), United Nations Human Right Council (UNHRC), the websites of some FBOs, gazettes and periodicals served as major sources of data collection. This was because these agencies and parastatals were directly or indirectly involved in the fight against coronavirus as well as its reportage.

\section{The coronavirus disease $\mathbf{2 0 1 9}$ pandemic in Nigeria}

On 11 February 2020, the name COVID-19 (coronavirus disease 2019) was selected by the World Health Organization. According to the director-general of the World Health Organization, the name was chosen based on the fact that it did not refer to any geographical location, animal, individual or group of people but only referred to the disease (WHO 2020). Reports from gazettes reveal that COVID-19 started in Wuhan, a city in the Hubei Province of China, in late 2019 and has since spread worldwide.

On 25 February 2020, Nigeria recorded its index case. According to the NCDC (2020), this index case was an Italian citizen who worked in Nigeria and returned from Milan, Italy, to Lagos. The NCDC is the body in charge of the management of COVID-19 in Nigeria. The functions of the NCDC during the period of coronavirus were to prevent, detect and control the disease; coordinate surveillance systems to collect, analyse and interpret data on the disease; support states in responding to small outbreaks and lead the response to large disease outbreaks; develop and maintain a network of reference and specialised laboratories for fighting the disease; and conduct, collate, synthesise and disseminate public health research to inform policy on the disease (Devex 2021; NCDC 2021).

The government of Nigeria took the COVID-19 pandemic with levity. On 01 April 2020, Nigeria had 140 active confirmed cases, two deaths and nine people recovered (Campbell 2020). It was after this that the government of Nigeria declared a lockdown.

\section{Insecurity and security agents' brutality}

After the declaration of lockdown in the various states of the federation, security agencies were empowered to enforce the governmental directives. These security agencies 
included the Nigerian army, Nigerian police force, Nigerian road safety commission and Nigerian civil defence, amongst others. They were charged with the responsibility of making sure that there was no interstate travel; ensuring that work, schools and marketplaces were closed; and stopping vehicular and human movement, except where based on necessity.

There were reports of excessive enforcement from the Nigerian security agencies. Nigeria's security personnel had a bad reputation for brutality, extortion and harassment even before the coronavirus pandemic and the lockdown imposed to contain the virus (Khalid 2020). It was alleged that security forces harassed and even killed desperate and hungry Nigerians in Warri, Uyo, Afikpo, Kaduna South, Aba North and Idemili North LGAs (Ewang 2020; Onyekwere 2020; Ventures 2020). Security agents went about destroying the shops of people who went out to sell or buy food (Adediran 2020; Sylvester 2020). In addition, security agents broke car windscreens and deflated the tires of motorcycles.

The citizens of the Warri, Uyo, Afikpo, Kaduna South, Aba North and Idemili North LGAs had no opportunity to prepare for the lockdown, and the problems were compounded by the failure to follow through with assistance in the form of the essentials of life such as food; promises were not being honoured, leading to the erosion of the citizens' faith in the authorities and the violation of lockdown orders (Jimoh et al. 2020).

Additionally, citizens who were on essential duties were flogged mercilessly by security agents. Citizens who sat outside their homes were flogged and humiliated. Effiong (2020:1) reported 'troubling videos showing policemen, military officers and other agents of the state torturing, flogging, harassing and humiliating citizens for staying outside'. According to the NHRC, security forces enforcing the lockdown in parts of Nigeria killed people even though the coronavirus itself did not kill (BBC 2020). This made the commission reiterate that 'Nigerian security forces have a reputation for brutality' (BBC 2020). Table 1 shows the brutality of security forces against ordinary Nigerians during the coronavirus pandemic.
Table 1 shows that the army, police, civil defence and other security agencies carried out human rights abuses. There was high-handed treatment of Nigerians during the coronavirus. The rich but especially the poor were harassed, abused and eventually saw the muzzle of the gun of Nigerian security personnel as their last sight. It is important to look at both the remote and immediate causes of the continuous perpetuation of brutality against Nigerians during the coronavirus.

\section{Causes of insecurity and security agents excesses}

The remote and immediate causes of the use of excessive force by Nigerian security forces during the coronavirus cannot be underestimated. These include corruption, lack of sensitisation and training, and lack of punishment after abuse of power.

\section{Corruption}

Corruption is evidenced by the unfair distribution of resources. In Warri LGA, on 01 April, Okowa announced the first 14 days of lockdown in the state, noting that the period of the lockdown would enable the state government to check the spread of the pandemic, adding that it was a worthwhile sacrifice by all to get it under control (Agency Report 2020). In Uyo, the government through the security agencies used barriers to stop people from entering their states (Reuters 2020). In the Aba North, Kaduna South and Idemili LGAs, there were restrictions on movement (Ekwebene et al. 2020; Reuters 2020).

The citizens of some LGAs in Nigeria were on total lockdown, including Warri, Uyo, Afikpo, Aba North, Kaduna South and Idemili North. Unfortunately, palliatives meant to cushion the effects of the hardship on the indigenous population were diverted to 'special individuals'. The palliatives were discovered after they provoked outrage in a nation reeling from spiralling food prices, high unemployment and antipolice brutality protests that turned violent in October 2020 (Dabang \& Ukomadu 2020). In Delta State (Warri), there was looting of goats, sheep and chickens (BBC 2020). In Kaduna South, people entered and looted the palliatives (BBC 2020). In Afikpo, the Ebonyi State government immediately started distributing palliatives when they discovered that the looting

TABLE 1: Cases of human rights abuse by security forces.

\begin{tabular}{|c|c|c|c|c|c|}
\hline S.no. & Insecurity issue & Date & Source & Local government area & State \\
\hline 1. & $\begin{array}{l}\text { A young man, Joe, was killed by army personnel } \\
\text { deployed to enforce a stay-at-home order in Delta State. }\end{array}$ & 02 April 2020 & $\begin{array}{l}\text { http://saharareporters.com/2020/04/02/army-kills- } \\
\text { man-delta-over-stay-home-order }\end{array}$ & Warri & Delta \\
\hline 2. & $\begin{array}{l}\text { Dr Daniel, a surgeon with the University of Uyo } \\
\text { Teaching Hospital, was beaten by a police sergeant } \\
\text { whilst on his way to work on a Friday evening. }\end{array}$ & 03 April 2020 & $\begin{array}{l}\text { https://www.independent.ng/police-officer-demoted- } \\
\text { for-assaulting-medical-doctor-in-akwa-ibom/ }\end{array}$ & Uyo & Akwa Ibom \\
\hline 3. & $\begin{array}{l}\text { Chidi lost his life after being shot by security forces } \\
\text { on the weekend. }\end{array}$ & 04 April 2020 & $\begin{array}{l}\text { https://www.independent.ng/covid-19-one-dies- } \\
\text { many-injured-as-task-force-youths-clash-in-ebonyi/ }\end{array}$ & Afikpo & Ebonyi \\
\hline 4. & $\begin{array}{l}\text { A petrol attendant, Chibuisi, was shot dead by a } \\
\text { policeman }\end{array}$ & 05 April 2020 & $\begin{array}{l}\text { https://punchng.com/trigger-happy-policeman-kills- } \\
\text { petrol-attendant-in-abia-2/ }\end{array}$ & Aba North & Abia \\
\hline 5. & $\begin{array}{l}\text { At least five people were killed and several others } \\
\text { injured. }\end{array}$ & 06 April 2020 & $\begin{array}{l}\text { https://www.channelstv.com/2020/04/07/ } \\
\text { five-killed-in-kaduna-as-security-operatives-enforce- } \\
\text { lockdown-order/ }\end{array}$ & Kaduna South & Kaduna \\
\hline 6. & Security personnel killed two boys at Nkpor & 15 April 2020 & $\begin{array}{l}\text { https://theeagleonline.com.ng/covid-19-lockdown- } \\
\text { two-killed-as-youth-pour-acid-on-policeman-in- } \\
\text { anambra/ }\end{array}$ & Idemili North & Anambra \\
\hline
\end{tabular}


of coronavirus palliatives was going on (Aliuna 2020). In Anambra, the palliatives were taken away to another location to avoid angry youths taking them away (Ovat 2020). Tijani (2020:1) lamented that 'the COVID-19 financial palliative that was meant to lift the suffering of the poorer Nigerians turned into COVID-419'. Media reports show that billions of naira were donated by the International Monetary Fund (IMF), European Union (EU) and community-minded individuals in Nigeria. The IMF approved US\$3.4 billion in emergency financial assistance under the Rapid Financing Instrument to support the Nigerian authorities' efforts to address the severe economic impact of the COVID-19 shock and the sharp fall in oil prices (Fouda 2020). Furthermore, on 14 April 2020, the European Union (EU) announced a EUR 50 million (N21 billion) contribution towards the implementation of a coordinated response to the COVID-19 pandemic in Nigeria (EU 2020).

Unfortunately, this fund has not been evenly accounted for. The Financial Times (2020) reported that theft does not stop even during the coronavirus in Nigeria. Obi-Ani (2021:8) termed the stealing of funds during the coronavirus 'crass corruption'. Hitherto, money such as the IMF and EU support has been lost to corruption, and this current loss may be business as usual. The Civil Society Legislative Advocacy Centre (2020) lamented that 'Nigeria's public finances suffer from a lack of accountability. Nigerian cronies use public budgets as a quasi-legitimate tool for personal enrichment and political adventures'. Most of the people who received the payment of conditional cash transfer and other relief materials were not the vulnerable poor indigenous population. There was no transparency and accountability in the distribution of the relief packages; hence most of the stimulus ended up in the wrong hands (Tijani 2020:1). One will infer that in order to survive citizens had no other alternative than to go out and look for what themselves and their family would eat. As evidence shows, some of these citizens were harassed, intimidated, abused and in some cases killed by security agents. It was on this basis that Olurounbi (2020) submitted that the Nigerian security response to COVID was deadlier than the disease. In Uyo, Sgt Alexander Edidiong hit Dr David Daniel Edet with a big stick on his left ulna and dislocated his left wrist, which was confirmed by X-ray, when the doctor pleaded for the police officer to allow him to go perform his essential duty (News Agency of Nigeria 2020).

\section{Lack of sensitisation and training}

Before the declaration of lockdown in the Warri, Uyo, Afikpo, Aba North, Kaduna South and Idemili North LGAs, there was no proper selection of the security personnel or sensitisation to the rules of engagement during the lockdown. There was no requisite training organised for them on how to enforce the executive orders during the period (Iweze 2020). This is the reason why they killed and harassed the indigenous population at will (Nzarga 2014; Verjee \& Kwaja 2020). This problem of brutality explains why Nigerians had no trust in security agents during the coronavirus. It was on this basis that Afolabi (2018) noted that security agencies in Nigeria need special training to contain situations such as this. Pandemics and epidemics are reoccurring phenomena in today's Nigerian society; hence, structures need to be put in place to prevent a reoccurrence of what happened during the 2020 coronavirus pandemic.

\section{Lack of punishment after abuse of power}

None of the security personnel who infringed brutally on the human rights of the indigenous population of the Warri, Uyo, Afikpo, Aba North, Kaduna South and Idemili North LGAs during the COVID-19 pandemic have been punished. Resident doctors at the University of Uyo Teaching Hospital (UUTH) Akwa Ibom threatened to down tools in the state over an alleged assault on one of their members by a security operative that went unpunished (News Agency of Nigeria 2020) In the media, the citizens were told that the erring security personnel would be punished according to the law; however, the available reports and evidence are to the contrary. Mugabi (2020) reported that the failure to punish those responsible for abuses emboldens security agents to play against the rules when executing their duties. Security agencies and their cronies exhibit a level of impunity and even deny that any human rights abuses were carried out. For instance, a petrol attendant was killed in Aba North by a security officer, but Nigeria's minister of information denied it. According to him, ' $[t]$ he petrol attendant was not actually killed by the policeman ... the policeman hit a Keke ${ }^{1}$, people were protesting so during the protest another motorist hit the petrol attendant' (Ukpong 2020). A Keke is a tricycle used for transportation in Nigeria. Most states have adopted the use of the Keke because it is less prone to causing road accidents.

\section{Faith-based organisations and the coronavirus in Nigeria}

Faith-based organisations are important agents of transformation in Nigeria. In Nigeria, 'FBO' refers to any organisation formed by a group of individuals on the basis of having the same religious belief. Faith-based organisations are stable, enduring and often the most trusted institutions in the community (Carver \& Reinert 2020). Göçmen (2013:495) revealed that FBOs provide a broad range of social welfare services and use their influence in policymaking for socially excluded groups. An 'FBO is any non-governmental organisation (NGO) that refers directly or indirectly to religion or religious values and functions as a welfare provider or as a political actor' (FACIT 2020). From the definitions above, FBOs look after the social, economic and cultural development of individuals and communities.

Nigeria is a country with three major religions, namely Christianity, Islam and African Traditional Religion. However, Christianity and Islam are the two major religions. 1.Keke is a tricycle which is used for transportation in Nigeria especially in the cities. 
There are various denominations of Christianity, such as Roman Catholic, Pentecostal, Orthodox and Presbyterian; whilst Islam has branches or sects such as the Sunnis and Shiites. Out of these denominations and sects have emanated organisations that provide health and educational services through their hospitals, clinics and maternal care units, schools and colleges, vocational training centres, seminaries and universities (Olarinmoye 2013). These are FBOs in Nigeria. Olarinmoye (2013) submits that they own economic institutions such as bookshops, hotels, banks, insurance, mass media and information and communication technology companies and are also prominent owners of real estate in the form of sacred cities and prayer camps, which cover thousands of hectares of land.

Faith-based organisations abound in Nigeria. They include the Christian Association of Nigeria, Nigerian InterReligious Council, Federation of Muslim Women's Association of Nigeria, Justice Development and Peace Commission, Christian Health Association of Nigeria, Nigerian Catholic Bishops' Conference, Pentecostal Fellowship of Nigeria, Christian Rural and Urban Development Association of Nigeria, Dunamis International Gospel Centre, Jama'atu Nasril Islam, Muslim Students Society, Young Men's Christian Association and Catholic Institute for Development, Justice and Peace, Enugu, amongst others. With regards to funding, FBOs get their funding from public-spirited individuals, units and organisations. Furthermore, they have as their donors: state and international organisations, NGOs, sector regulators (religious networks, state ministries and agencies) and their clients (users of their services) (Olarinmoye 2013).

During the COVID-19 pandemic, FBOs made large donations to the Federal Government of Nigeria. The Dunamis International Gospel Centre donated medical equipment worth millions of naira to the Federal Capital Territory Administration to combat the COVID-19 outbreak (Ewepu 2020). Furthermore, Deeper Christian Life Ministry donated the sum of N50 million to the Federal Government of Nigeria (The Vanguard 2020). In addition, Bishop David Oyedepo, the founder of the Living Faith Church Worldwide (Winners' Chapel International), made donations of ambulances, test kits, personal protective equipment to the Lagos and Ogun state governments, to assist in the fight against the COVID-19 scourge in Nigeria (Falade 2020). Faith-based organisations tried especially to empower the Nigerian government in the fight against COVID-19.

\section{Faith-based organisations and the security of citizens during the coronavirus disease 2019 pandemic}

Little is known about the social role played by FBOs in the Warri, Uyo, Afikpo, Aba North, Kaduna South and Idemili North LGAs during the COVID-19 period. The life of the ordinary Nigerian has not been touched by these FBOs because the FBOs donated money to the federal government of Nigeria without a commensurate payment to the Nigerian citizens who are their members. Most donations were made directly to the federal government of Nigeria with little attention paid to the ordinary Nigerian (Taiyese 2020; The Vanguard 2020).

Several recommendations are made with regards to the role of FBOs and the security situation in Nigeria during the coronavirus:

- Faith-based organisations should start providing relief materials to members of their community in their various houses in the Warri, Uyo, Afikpo, Aba North, Kaduna South and Idemili North LGAs. They should not concentrate their social role on their members only but also assist other members of the community. Rice, beans, garri, other food items and even cash can be given to members of the community (mostly the indigent) so as to enable them to adhere to the social distancing and lockdown mandates declared by the federal and state governments.

- Faith-based organisations should help to sensitise the security agents of the Warri, Uyo, Afikpo, Aba North, Kaduna South and Idemili North LGAs. They can do this by writing rules of engagement on a pamphlet and ensuring that it is shared with the security agents in their community. They can also join security agents in enforcing the lockdown, and in the process identify problems with the enforcement strategy. When they have identified these problems, they should advise the security agents accordingly.

- Furthermore, FBOs should locate the relations of the victims of security excesses and reach out to them economically and socially. They can do this by ensuring that they provide for the remaining members of the family. Faith-based organisations should try to get the details of those killed by the security agents, their phone number, names and places where they were killed to enable them to take appropriate and prompt action (French Press Agency 2020). When FBOs promote physical and mental well-being, when they discourage illegal or reckless behaviour and when they advocate for ethical conduct, they are also indirectly promoting the health of their members and all citizens (Carver \& Reinert 2020).

- Finally, FBOs should meet with the chiefs of security agencies and ensure that those security agents who were indicted for various human rights abuses are made to face the strong arm of the law. When other security agents see punishment meted out to their erring colleagues, they will follow the rules of engagement.

\section{Conclusion}

The engagement of FBOs in the contemporary security challenges in Nigeria would protect the lives and the human rights of Nigerians. The reason why security agents have 
continued to trample on the rights of Nigerians during this COVID-19 pandemic period is predominantly based on the fact that they were not properly trained on and sensitised to the rules of engagement during emergency cases in the Warri, Uyo, Afikpo, Aba North, Kaduna South and Idemili North LGAs. Furthermore, the government failed to properly distribute palliatives. Faith-based organisations can right this wrong by ensuring that they share food items with members of their immediate community so that citizens can adjust to the lockdown announced by the government.

\section{Acknowledgements Competing interests}

The authors declare that they have no financial or personal relationships that may have inappropriately influenced them in writing this article.

\section{Authors' contributions}

F.C.U. and C.T.N. contributed equally to the design and implementation of the research, to the analysis of the results and to the writing of the manuscript.

\section{Ethical considerations}

Ethical clearance was not needed for the study. This article followed all ethical standards for research without direct contact with human or animal subjects.

\section{Funding information}

This research received no specific grant from any funding agency in the public, commercial or not-for-profit sectors.

\section{Data availability}

Data sharing is not applicable to this article as no new data were created or analysed in this study.

\section{Disclaimer}

The views and opinions expressed in this article are those of the authors and do not necessarily reflect the official policy or position of any affiliated agency of the authors.

\section{References}

Aborisade, R.A., 2021, 'Accounts of unlawful use of force and misconduct of the Nigerian Police in the enforcement of COVID-19 measures', Journal of Police and Criminal Psychology 1-13. https://doi.org/10.1007/s11896-021-09431-4

Adediran, I., 2020, 'Coronavirus Shutdown: Police arrest officers seen in video destroying drinks', viewed 27 March 2020, from https://www.premiumtimesng. com/coronavirus/384361-coronavirus-shutdown-police-arrest-officers-seen-invideo-destroying-drinks.html.

Adurokiya, E. \& Agborh, A., 2020, COVID-19 lockdown: Man shot dead in Warri, viewed 02 April 2020, from https://tribuneonlineng.com/covid-19-lockdownman-shot-dead-in-warri/.

Afolabi, A., 2018, 'Security agencies need special training to contain menace', The Guardian, 16 February, p.1.

Agency Report, 2020, 'COVID-19: Okowa extends lockdown in Delta' viewed 28 April 2020, from https://www.premiumtimesng.com/coronavirus/390349-covid-19okowa-extends-lockdown-in-delta.html.
Alaribe, U. \& Ugbor, E., 'COVID-19: Taskforce kills keke operator in Aba, another survives attack', Vanguard, 17 April, p. 1.

Aliuna, G., 2020, 'Tension as Ebonyi govt shares palliatives to students', DailyPost, 27 October, p. 1.

Amnesty International, 2020, 'Nigeria: authorities must uphold human rights in fight to curb COVID-19', viewed 11 August 2020, from https://www.amnesty.org/en/ latest/news/2020/04/nigeria-covid-19/.

Amzat, J., Aminu, K., Kolo, V.I., Akinyele, A.A., Ogundairo, J.A. \& Danjibo, M.C., 2020, 'Coronavirus outbreak in Nigeria: Burden and socio-medical response during the first 100 days', International Journal of Infectious Diseases 9(8), 218-224.

BBC, 2020, Coronavirus: Security forces kill more Nigerians than Covid-19, viewed 16 April 2020, from https://www.bbc.com/news/world-africa-52317196.

Bloor, M. \& Wood, F., 2011, Phenomenological Methods, Research Methods, Sage, New York.

Campbell, J., 2020, 'Lagos and Abuja on Lockdown to Stop Coronavirus in Nigeria', Council on Foreign Relations, viewed 01 April 2020, from https://www.cfr.org/ blog/lagos-and-abuja-lockdown-stop-coronavirus-nigeria.

Carver, V.C. \& Reinert, B.R., 2020, 'Faith-based organizations', viewed 23 March 2020, from https://www.encyclopedia.com/education/encyclopedias-almanacstranscripts-and-maps/faith-based-organizations.

Dabang, P. \& Ukomadu, A., 2020, 'In Nigeria, looters target government warehouses stocked with COVID-19 relief', viewed 21 March 2020, from https://www.reuters. com/article/uk-health-coronavirus-nigeria-food-idUKKBN27POYZ.

DEVEX, 2021, 'Nigeria Centre for Disease Control (NCDC)', viewed 11 March 2021 from https://www.devex.com/organizations/nigeria-centre-for-disease-controlncdc-76466.

Effiong, I., 2020, COVID-19 lockdown: No to torture of citizens by security agents, viewed 01 April 2020, from https://www.thecable.ng/covid-19-lockdown-no-totorture-of-citizens-by-security-agents.

Ekwebene, O.C, Ogbuagu C.N, Yanmeer, S.T, Orji, A.E. \& Ani, U.C, 2020, 'Perception, Knowledge and Response to COVID-19 Pandemic among Traders in Three Major Markets in Anambra State, Nigeria', International Journal of Health Sciences and Research 10(12), 213-221.

EU, 2020, EU Boosts Nigeria's COVID-19 Response with N21 Billion Contribution viewed 14 April 2020, from https://eeas.europa.eu/delegations/nigeria/77571/ eu-boosts-nigeria\%E2\%80\%99s-covid-19-response-n21-billioncontribution en\#: : text=EU\%20Boosts\%20Nigeria's\%20COVID\%2D19\%20Response $\% 20$ with $\% 20$ N21\%20Billion\%20Contribution,14\%2F04\%2F2020\&text=The \%20 with\%20N21\%20Billion\%20Contribution,14\%2F04\%2F2020\&text=The\%20 Europea
Nigeria.

Ewang, A., 2020, 'Multiple Killings in Nigeria's Kaduna State', viewed 31 March 2020 from https://www.hrw.org/news/2020/07/31/multiple-killings-nigerias-kadunafrom

Ewepu, G., 2020, 'COVID-19: Dunamis Church donates medical equipment to FCTA', The Vanguard, 26 March, p. 1.

FACIT, 2020, Faith-based organizations and exclusion in European cities, viewed 09 March 2021, from http://cordis.europa.eu/result/rcn/55806_en.html.

Falade, O., 2020, COVID-19 lockdown: Oyedepo's living faith church donates ambulances, test kits, food, others to Lagos, Ogun States, viewed 31 March 2020, from https:// www.thenewsguru.com/news/nigeria-news/article/covid-19-lockdown-oyedeposliving-faith-church-donates-ambulances-test-kits-food-others-to-lagos-ogun-states/.

Financial Times, 2020, 'Africa's Covid-19 corruption: 'Theft doesn't even stop during a pandemic', viewed 11 March 2020, from https://www.ft.com/content/617187c2 ab0b-4cf9-bdca-0aa246548745.

Fouda, L.M., 2020, 'IMF Executive Board Approves US\$ 3.4 Billion in Emergency Support to Nigeria to address the COVID-19 Pandemic', viewed 28 April 2020 from https://www.imf.org/en/News/Articles/2020/04/28/pr20191-nigeria-imfexecutive-board-approves-emergency-support-to-address-covid-19.

French Press Agency, 2020, Security forces kill 18 in Nigeria over virus lockdown, viewed 17 April 2020, from https://www.dailysabah.com/world/africa/securityforces-kill-18-in-nigeria-over-virus-lockdown.

Fuwape, I.A., Okpalaonwuka, C.T. \& Ogunjo, S.T., 2021, 'Impact of COVID-19 pandemic lockdown on distribution of inorganic pollutants in selected cities of Nigeria', Air Quality, Atmosphere \& Health 14(2), 149-155.

GardaWorld, 2020, Nigeria: Lockdown extended in Delta state as of 14 April , viewed 15 April 2020, from https://www.garda.com/crisis24/news-alerts/332756/ nigeria-lockdown-extended-in-delta-state-as-of-april-14-update-11.

Göçmen, I., 2013, 'The role of faith-based organizations in social welfare systems: A comparison of France, Germany, Sweden, and the United Kingdom', Non-profit and Voluntary Sector Quarterly 42(3), 495. https://doi.org/10.1177/0899764013482046

Iweze, D.O., 2020, 'Covid-19 and Nigeria's Counterinsurgency Operations in the Northeast', viewed 04 June 2020, from https://kujenga-amani.ssrc. org/2020/06/04/covid-19-and-nigerias-counterinsurgency-operations-in-thenortheast/.

Jimoh, A.M., Abuh, A., Onyedika-Ugoeze, N., Ogune, M., Otaru, A., Ogugbuaja, C., Okafor, C., Neme, S., Akhaine, S. \& Agboluaje, R., 2020, 'Lockdown incites anger', TheGuardian, 03 April, p. 1.

Khalid, I., 2020, 'Mixed message from the president', BBC News, viewed 12 March 2021, from https://www.bbc.com/news/world-africa-52317196.

Mugabi, I., 2020, 'COVID-19: Security forces in Africa brutalizing civilians under lockdown', viewed 20 April, 2020, from https://www.dw.com/en/covid-19security-forces-in-africa-brutalizing-civilians-under-lockdown/a-53192163. 
NAN, 2020, 'COVID-19: Umahi imposes dusk to dawn curfew on Ebonyi', TheGuardian, 18 April, p. 1.

NCDC, 2021, About NCDC, viewed 11 March 2021, from https://ncdc.gov.ng/ ncdc.

News Agency Of Nigeria, 2020, Lockdown: A'Ibom doctors threaten strike over alleged police officer's assault on member, viewed 04 May 2020, from pulse.ng/news/ local/lockdown-aibom-doctors-threaten-strike-over-alleged-police-officersassault-on-member/mbewczn.

Nigeria Centre for Disease Control, 2020, First case of corona virus disease confirmed in Nigeria, viewed 28 February 2020, from https://ncdc.gov.ng/news/227/firstcase-of-corona-virus-disease-confirmed-in-nigeria.

Nzarga, F.D., 2014, 'An analysis of human rights violation by the Nigerian security services', Journal of Law, Policy, and Globalization 30, 1-8.
Olarinmoye, O., 2013, 'Accountability in faith-based organizations in Nigeria', Transformation: An International Journal of Holistic Mission Studies 31(1), 52. https://doi.org/10.1177/0265378813501733

The Civil Society Legislative Advocacy Centre, 2020, 'Nigeria, Nigeria, IMF and Covid-19', viewed 16 July 2020, from https://www.transparency.org/en/blog/ nigeria-imf-covid-19.

The Vanguard, 2020, 'COVID-19: Deeper Life Bible Church donates N50m to FG', The Vanguard, 09 April, p. 1.

Tijani, T., 2020, 'Money, COVID-419 and pandemic corruption', The Guardian, 16 April, p. 1.

Ukpong, C., 2020, Lai Mohammed lied about police killing of petrol attendant-Abia govt, p. 1, viewed 25 April 2020, from https://www.premiumtimesng.com/news/ headlines/389711-lai-mohammed-lied-about-police-killing-of-petrol-attendantabia-govt.html. 